\title{
Antagonis Soluble Fms-Like Tyrosine Kinase 1 (sFlt-1) dan Soluble Endoglin (sEng) pada Preeklamsia
}

\author{
Mohd. Andalas, ${ }^{1}$ Harapan ${ }^{2}$
}

\begin{abstract}
Proangiogenic factor signal transduction like vascular endothelial growth factor (VEGF), placental growth factor (PlGF) and tissue growth factor â-1 (TGFâ-1) are important to angiogenesis and vascular health in pregnancy. In preeclampsia (PE) concentration of fms-like tyrosine kinase-1 (sFlt-1) and soluble endoglin (sEng) are increase significantly. Base on analysis from resent research shown that sFlt-1 and sEng inhibit angiogenic factor signal transduction by competition - in result angiogenic factor can't bind to their receptor. sFlt-1 and sEng are potential used as preeclampsia therapy because sFlt- 1 and sEng have main role in PE pathogenesis. We suggest that the research to find out effective sFlt-1 and sEng antagonist have to conduct in the next time.
\end{abstract}

Keywords: preeclampsia, sFlt-1 sEng, VEGF, PlGF, TGFâ-1

Hipertensi pada kehamilan merupakan penyebab morbiditas dan mortalitas neonatal serta bertanggung jawab terhadap $17,6 \%$ kematian maternal, bahkan menjadi penyebab ke-3 kematian ibu setelah tromboembolisme dan hemoragik. Angka kejadian komplikasi hipertensi pada kehamilan berkisar antara 12-22\% dengan akibat yang bervariasi, dari ringan sampai berat. ${ }^{1}$ Salah satu jenis hipertensi pada kehamilan adalah preeklampsia (PE). PE merupakan suatu keadaan dimana terjadi peningkatan tekanan darah dan proteinuria yang terjadi setelah 20 minggu umur gestasi dan setidaknya 48 jam setelah postpartum. ${ }^{2}$ Preeklamsi terjadi sekitar 3-5\% kehamilan di seluruh dunia, namun angka ini lebih tinggi pada negara berkembang yaitu sekitar 5-8\%., 3

Tingginya angka kejadian preeklamsi ini merupakan permasalahan yang harus mendapat perhatian tersendiri dalam dunia kedokteran mengingat komplikasi yang ditimbulkannya serta belum adanya modalitas diagnostik yang efektif. ${ }^{6,7}$ Selain itu managemen medikamentosa yang ada

\footnotetext{
1 Penulis untuk korespondensi : SMF Obstetrik dan Ginekologi Fakultas Kedokteran Universitas Syiah Kuala / RSU Dr. Zainoel Abidin Banda Aceh

E-mail: $\underline{m}$ andalas@yahoo.com Telp/Fax: 0651 - 29608

2 Fakultas Kedokteran Universitas Syiah Kuala, Banda Aceh
}

sekarang hanya untuk mencegah timbulnya komplikasi. Oleh karena itu perlu di cari suatu suatu terapi medikamentosa yang memiliki target site spesifik pada jalur utama patogenesis PE.

Patogenesis PE sampai sekarang masih banyak diperdebatkan, namun beberapa penelitian menyatakankan bahwa ketidakseimbangan faktor angiogenik sangat berperan dalam patogenesis PE yaitu terjadinya peningkatan soluble fms-like tyrosine kinase-1 (sFlt-1) dan soluble endoglin (sEng) yang memiliki aktifitas antiangiogenik dan terjadinya penurunan konsentrasi faktor proangiogenik seperti placental growth factor (PIGF) dan transforming growth factor-âl (TGFâ1). ${ }^{8-16}$

Semakin kuatnya dukungan terhadap peran sFlt1, sEng, PlGF, dan TGF-â1 dalam patogenesis PE, menunjukkan bahwa faktor-faktor tersebut memiki peran utama dalam patogenesis PE sehingga dapat dijadikan sebagai target site dalam mengembangkan obat PE pada masa mendatang. Dukungan terhadap hal ini juga diperoleh dari arah pengembangan modalitas dignostik PE yang menggunakan faktor angiogenik tersebut sebagai biomarker untuk diagnostik dan predikasi perkembangan PE. ${ }^{10,17-25}$

Berdasarkan analisis yang dilakukan oleh beberapa peneliti menunjukkan bahwa peningkatan 
sFlt-1 dan sEng memegang peran yang lebih dominan dalam patogenesis PE. Peningkatan kadar sFlt-1 dan sEng pada masa kehamilan menyebabkan gangguan dalam transduksi sinyal proses angiogenesis sehingga proses angiogenesis terganggu yang merupakan penyebab utama PE. ${ }^{8}$ Oleh karena itu tulisan ini mencoba menganalisis kemungkinan pengembangan antagonis sFlt-1 dan sEng sebagai arah terapi PE yang lebih spesifik.

\section{PEMBAHASAN}

Hipertensi pada kehamilan diklasifikasikan dalam 4 kelompok yaitu hipertensi gestasional, preeklampsia, hipertensi kronik dan hipertensi kronik yang disertai preeklampsia (preeclampsia superimposed on chronic hypertension). ${ }^{2}$ Preeklampsia adalah suatu keadaan pada kehamilan yang ditandai dengan hipertensi dan proteinuria yang muncul setelah 20 minggu umur gestasi dan terjadi sekitar 5-7\% kehamilan di seluruh dunia.,228 Dikatakan hipertensi jika tekanan darah sistolik lebih dari $140 \mathrm{mmHg}$ atau tekanan darah diastolik lebih dari $90 \mathrm{mmHg}$ dan proteinuria didefinisikan sebagai terdapatnya protein setidaknya $100 \mathrm{mg} / \mathrm{dl}$ dalam spesimen urin random pada interval 4 atau didapatkannya protein lebih dari 300mg dalam 24 jam atau diperoleh protein pada sampel urin tunggal lebih dari $30 \mathrm{mg} / \mathrm{mmol}$ atau tes dipstick lebih dari positif $1 .^{2,4}$

Banyak faktor yang berhubungan dengan PE. Berdasarkan penelitian-penelitian yang telah dilakukan menunjukkan bahwa faktor resiko timbulnya PE adalah obesitas pada ibu, resistensi insulin, hiperlipidemia, hipertensi, penyakit ginjal dan trombofilia. ${ }^{29,30}$ Selain itu, umur ibu saat mengandung yaitu dibawah 20 tahun dan diatas 3540 tahun, status ekonomi yang rendah, nulliparitas, PE pada kehamilan sebelumnya, stress, antifosfolipid antibodi sindrom juga merupakan faktor resiko timbulnya PE. ${ }^{2,31}$

\section{Perkembangan Diagnosis Preeklamsia: Dukungan Terhadap sFlt-1 dan sEng}

Berbagai biomarker telah digunakan oleh peneliti untuk mendeteksi dan memprediksi PE dalam beberapa tahun terakhir ini. Diantaranya adalah pentraxin (PTX3), granulysin plasma, placental protein 13, pregnancy-associated plasma protein A, (PAPP-A), apolipoprotein $\mathrm{E}$, inhibin $\mathrm{A}$ dan activin $A{ }^{32,33,34}$ Namun pengembangan deteksi dan prediksi PE tampaknya lebih mengarah ke molekul PIGF, sFlt-1 dan sEng. Berbagai penelitian yang menunjukkan sensitifitas dan spesifisitas sFlt1 dan PIGF sebagai biomarker dan prediktor PE dirangkum pada Tabel 1 dan Tabel 2.

Tabel 1 Hasil Tes sFlt-1 yang Digunakan untuk Mendeteksi dan Memprediksi PE 22,35,36

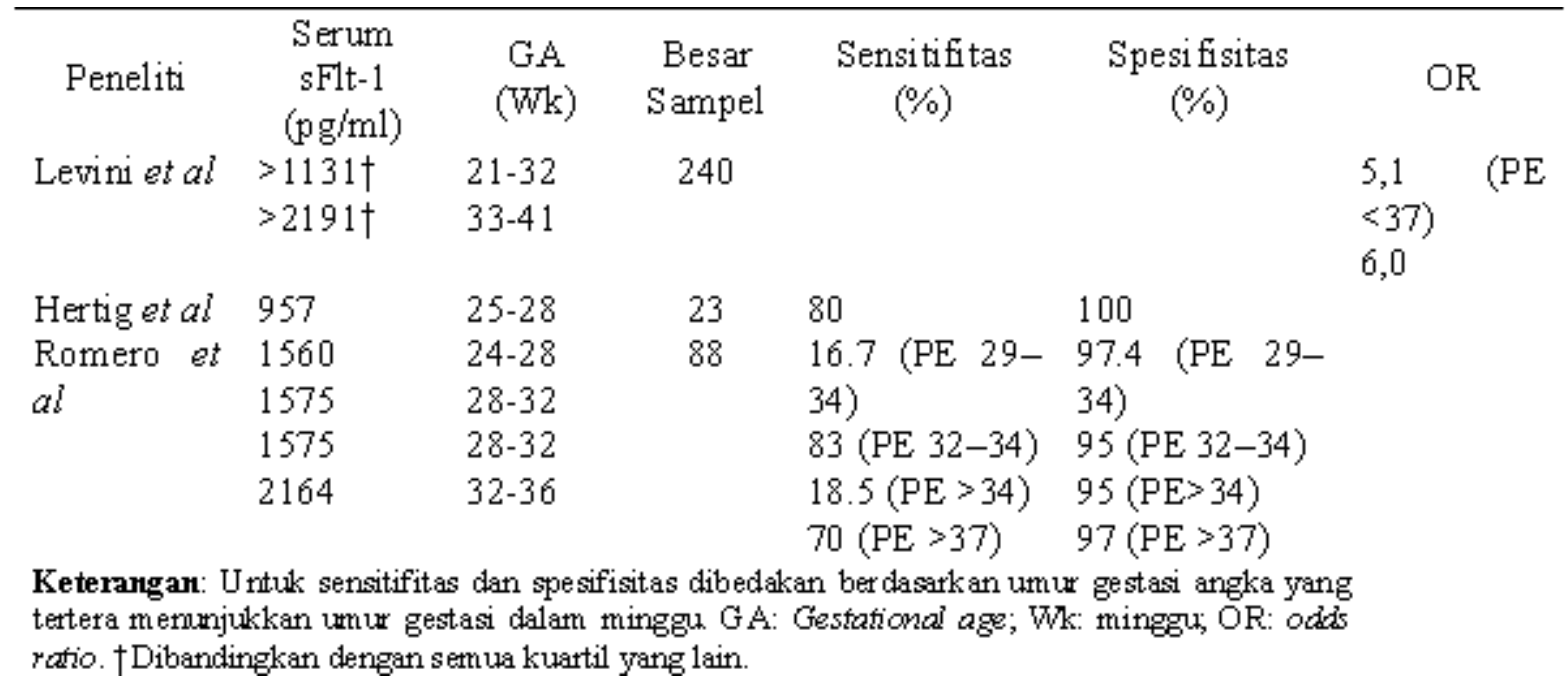


Tabel 2 Hasil Tes PIGF yang Digunakan untuk Mendeteksi dan Memprediksi PE 17,18,20,21,24,35,37

\begin{tabular}{|c|c|c|c|c|c|c|c|}
\hline Peneliti & $\begin{array}{l}\text { Serum } \\
\text { PIGF } \\
\text { (pg/ml) }\end{array}$ & $\begin{array}{l}\text { GA } \\
\text { (Wk) }\end{array}$ & $\begin{array}{c}\text { Besar } \\
\text { Sampel }\end{array}$ & $\begin{array}{l}\text { ST } \\
(\%)\end{array}$ & $\begin{array}{l}\text { SP } \\
(\%)\end{array}$ & OR/RR & ROC \\
\hline Thadhani et al & $<12 \dagger$ & 10 & 200 & & & $14.7 \dagger$ & 0,69 \\
\hline Tidwell et al & $\begin{array}{l}<32 \\
<90\end{array}$ & $\begin{array}{l}5-15 \\
16-20\end{array}$ & 39 & $\begin{array}{c}90,9 \\
66,7\end{array}$ & $\begin{array}{l}90,5 \\
88,9\end{array}$ & $\begin{array}{l}95 \\
16\end{array}$ & \\
\hline Chappell et al & $\begin{array}{l}\text { PlGF } \\
\text { formula }\end{array}$ & $\begin{array}{l}20 \\
24\end{array}$ & 65 & & & & $\begin{array}{l}0,72 \\
0,85\end{array}$ \\
\hline Suet al & $\mathrm{MOM}=0.76$ & $14-19$ & 254 & 70 & 70 & $\begin{array}{l}2.5 \text {-fold per } 0.1 \\
\text { MOM }\end{array}$ & 0,79 \\
\hline Polliotti et al & $<80.8$ & 17 & 80 & & & 4,2 & 0,799 \\
\hline Levine et $a l$ & $\begin{array}{l}<87 \dagger \\
<363 \dagger\end{array}$ & $\begin{array}{c}13-20 \\
21-32\end{array}$ & 240 & & & $\begin{array}{l}7,4(\mathrm{PE}<37) \\
7,9(\mathrm{PE}<37)\end{array}$ & \\
\hline Levine et al & $<118 \dagger \ddagger$ & $21-32$ & 240 & & & $22,5(\mathrm{PE}<37)$ & \\
\hline
\end{tabular}

Keterangan: PE: Preeklamsia; OR: odds ratio; RR: relative risk; ROC: receiver operator characteristic curve area; MOM: multiple of the median; ST: sensitifitas; SP: spesifisitas. $\dagger$ Dibandingkan dengan semua kuartil yang lain, $\ddagger$ konsentr asi P1GF urin.

Penelitian yang terakhir mendapatkan bahwa sEng yang terdapat di dalam serum wanita hamil dapat dijadikan sebagai prediktor dan biomarker untuk PE yang baik..$^{9,11,25,38}$ Penelitian yang ditujukan untuk mengetahui biomarker mana yang paling sesuai digunakan untuk mendeteksi dan memprediksi PE memperlihatkan bahwa kombinasi (sFlt-1+sEng)/(PlGF+TGF-â1) didapatkan hasil confidence interval (CI) 95\% mencapai $0,90-0,98$ dan ROC $0,94 .{ }^{9}$ Untuk lebih jelasnya diberikan pada Tabel 3 .

Tabel 3 Kombinasi Parameter yang Digunakan untuk Mendeteksi dan Memprediksi PE ${ }^{9}$

\begin{tabular}{lrccc}
\hline \multicolumn{1}{c}{ Parameter } & Cut of & $\begin{array}{c}\text { False-Positive Rate } \\
(\%)\end{array}$ & ROC & $95 \% \mathrm{CI}$ \\
\hline sFlt-1 (pg/ml) & $2.705,8$ & 45 & 0,76 & $0,68-0,84$ \\
sEng (pg/ml) & $4.903,6$ & 41 & 0,83 & $0,75-0,91$ \\
sFlt-1/PlGF & 20,5 & 33 & 0,85 & $0,78-0,92$ \\
sEng/TGF- $\beta 1$ & 2,0 & 21 & 0,89 & $0,80-0,97$ \\
(sFlt-1/sEng)/(P1GF/TGF- & 3,0 & 10 & 0,94 & $0,90-0,98$ \\
B1) & & & & \\
\hline
\end{tabular}

\section{Faktor Proangiogenik pada Kehamilan}

Pada perkembangan kehamilan normal banyak faktor proangiogenik yang diperlukan namun pada keadaan PE kerja dari faktor proangiogenik ini terganggu. Diantara faktor proangiogenik tersebut adalah adalah: a). Vascular endothelial growth factor (VEGF), b). PIGF dan c). tissue growth factor â-1 (TGFâ-1).

Vascular endothelial growth factor adalah salah satu faktor yang penting untuk pertumbuhan dan kehidupan endotel, menginduksi angiogenesis dan proliferasi sel endotel serta berperan penting dalam vaskulogenesis. VEGF memiliki banyak reseptor, yang paling berperan pada plasentasi adalah $V E G F$ receptor 1 (VEGFR-1) atau Flt-1 dan VEGF receptor 2 (FLK-1/kinase-insert domain region (KDR)). ${ }^{2,39}$ Meskipun VEGF total menunjukkan peningkatan ringan pada preeklampsia, namun pada preeklampsia VEGF terikat oleh sFlt- $1 .{ }^{10}$ Soluble fms-like tyrosine kinase-1 mempunyai afinitas yang lebih kuat terhadap VEGF daripada PIGF sehingga jumlah VEGF bebas menurun pada sirkulasi maternal sedangkan VEGF meregulasi vasodilatasi 
pembuluh darah melalui produksi NO dan prostasiklin. ${ }^{40}$

Placental growth factor merupakan glikoprotein homodimerik termasuk dalam famili VEGF, terdiri dari 132 asam amino dengan berat molekul 50kDa dan berfungsi sebagai mediator angiogenesis yang penting dalam menginduksi proliferasi, migrasi dan aktivasi sel endotel. P1GF diekspresikan pada plasenta, sel endotel vena umbilikal dan choriocarcinoma cell line. Selain itu, PlGF diproduksi oleh sitotrofoblas, sinsitiotrofoblas dan tropoblas ekstravili pada plasenta. Berbagai studi menemukan bahwa konsentrasi PlGF lebih rendah dari kehamilan yang normal, berkisar 3 sampai 10 kali lebih rendah. ${ }^{17,19}$

Tissue growth factor $\hat{\text { a }} 1$ memiliki efek bifungsi pada sel endotel secara in vitro, dan mampu menstimulasi serta menghambat proliferasi sel endotel ${ }^{41}$ Pada satu percobaan tampak bahwa TGFâ1 dalam dosis rendah bersifat menstimulasi sedangkan dalam dosis tinggi menghambat proliferasi. ${ }^{41}$ TGF $\hat{a}-1$ mengatur ekspresi dan atau aktivasi metalloprotease (MMP) 2 dan 9. MMP 2 dan 9 yang berperan dalam degradasi matriks ekstraselular sehingga menginisiasi angiogenesis. Normalnya, TGFâ diikat oleh ALK1 dan ALK5 untuk mengaktivasi signaling endoglin pada angiogenesis. Pada PE, TGFâ justru berikatan dengan sEng sehingga menjadi tidak aktif dan signaling angiogenesis terhambat. ${ }^{42}$

\section{Fungsi Normal Flt-1 dan Endoglin}

Molekul Flt-1 juga dikenal dengan vascular endothelial growth factor receptor 1 (VEGFR-1). Produksi Flt-1 melalui sekresi secara endogen menghasilkan potongan Flt-1 yang bersifat larut disebut soluble Flt-1 (sFlt-1) yang dilepaskan ke sirkulasi. sFlt-1 adalah suatu jenis pemotongan alternatif dari Flt-1. Flt-1 terdiri dari domain liganbinding ekstraseluler, domain transmembran dan domain sitoplasmik. sFlt-1 merupakan bentuk Flt-1 yang kehilangan domain sitoplasmik dan transmembran tetapi masih memiliki domain ligandbinding ekstraseluler. ${ }^{26}$ Penelitian terbaru menunjukkan bahwa terjadi peningkatan produksi sFlt-1 oleh plasenta dan juga pada serum pasien PE dan berkorelasi dengan tingkat keparahan PE yang terjadi. ${ }^{13,43}$
Endoglin (CD105) merupakan glikoprotein transmembran homodimerik dengan berat molekul 180kDa. Endoglin dengan lapisan luar 561 asam amino, merupakan domain transmembran yang bersifat hidrofobik dan memiliki ekor berupa 47 residu sitoplasma yang secara kuat diekspresikan oleh sel endotel dan sinsititrofoblas. ${ }^{42}$ Endoglin terdiri dari disulfide-linked extracellular region dan ekor sitoplasma untuk proses fosforilasi. Terdapat 2 variasi bentuk endoglin berdasarkan tempat pemotongan pada ekor sitoplasmiknya yaitu $\mathrm{S}$ dan L. Endoglin-L terdiri dari 633 asam amino dengan 47 asam amino pada ekor sitoplasmiknya sedangkan endoglin-S terdiri dari 600 asam amino dengan 14 asam amino pada ekor sitoplasmiknya. Endogin juga diekspresikan oleh monosit, prekursor dan subpopulasi stem sel..$^{26,34,44}$ Penelitian menunjukkan bahwa pada pasien PE terdapat peningkatan konsentrasi sEng secara bermaknanamun belum ada laporan yang nenunjukkan bahwa terdapat mutasi pada gen endoglin berkaitan dengan PE. ${ }^{11,12}$

Endoglin merupakan koreseptor homodimerik untuk anggota superfamili TGF yang meliputi TGFâ-1 dan â-3 serta BMP-2, BMP-7, dan activin A. ${ }^{39}$ TGF tipe I memiliki peran pada proses hematopoesis, perkembangan kardiovaskular dan angiogenesis. Endoglin memodulasi signal TGFâ dengan cara berinteraksi dengan reseptor TGF-â??I dan II. Endoglin merupakan protein terkait hipoksia yang diekspresikan dalam jumlah besar pada sel endotel angiogenik. ${ }^{11,42}$ Endoglin terlokalisasi di caveolae, di mana ia berinteraksi dengan $N O$ synthase..$^{45}$ Penemuan ini mengimplikasikan signal TGFâ-1 dan NO berperan dalam mekanisme sindrom PE. ${ }^{42}$

Model interaksi endoglin dengan jalur TGFâ/ ALK-1 and TGFâ/ALK-5 diberikan pada Gambar 1. Domain ektraseluler and sitoplasmik endoglin berinteraksi dengan ALK1 dan ALK5. Kemudian endoglin memainkan peran penting pada penyinyalan TGFâ dengan merangsang jalur ALK1/ Smad1, ALK5/Smad2 (panah hijau) dan menghambat jalur ALK5/Smad3 (panah merah) yang kemudian akan meregulasi gen Id1, eNOS dan plasminogen activator inhibitor-1 (PAI-1). ${ }^{44}$ 


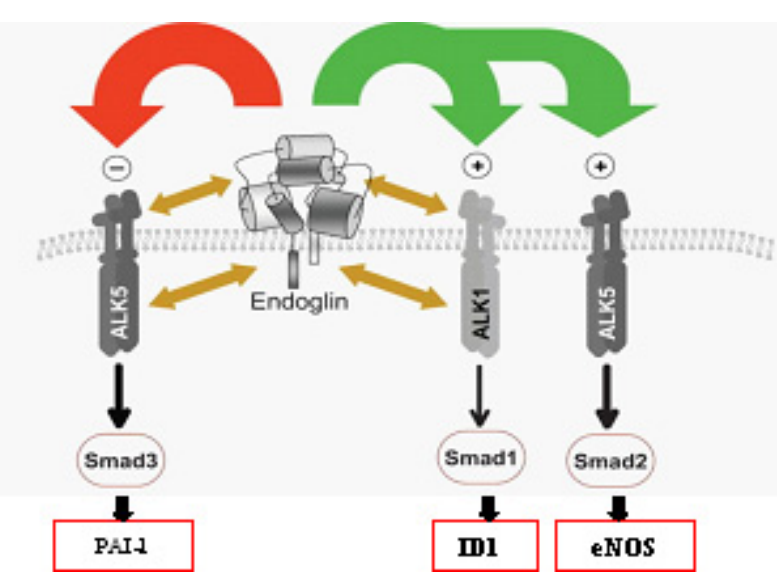

Gambar 1. Peranan Endoglin dalam Tubuh (Diadaptasi Bernabeu et al, 2007). ${ }^{44}$

\section{Molekuler Patogenesis Preeklamsia: Arah Pengembangan Antagonis sFlt-1 dan sEng}

Patogenesis preeklampsia secara umum terdiri dari 2 tahapan proses. Tahap pertama merupakan tahap asimtomatik yang ditandai oleh perkembangan plasenta yang abnormal selama trimester I yang mengakibatkan insufisiensi plasenta dan pelepasan beberapa material plasenta ke dalam sirkulasi maternal. Tahap kedua yaitu tahap simtomatik atau sindrom maternal yang ditandai oleh hipertensi, gangguan ginjal, dan proteinuria. ${ }^{10}$

Patogenesis preeklampsia sangat kompleks karena melibatkan faktor genetik, imunologi dan faktor lingkungan yang saling berinteraksi. Pada wanita PE terdapat peningkatan tonus simpatis, peningkatan respons terhadap epineprin dan lebih sensitif terhadap angiotensin II. Selain itu juga terdapat penurunan mediator vasoaktif seperti prostaglandin $\mathrm{I}_{2}\left(\mathrm{PGI}_{2}\right)$ dan $\mathrm{NO}$ serta terdapat peningkatan tromboksan $\mathrm{A}_{2}$ dan endotelin. ${ }^{26}$

Namun demikian patogenesis PE yang sampai saat ini dipercaya adalah terjadinya ketidakseimbangan faktor angiogenenik yaitu ketidakseimbangan antara faktor proangiogenik dan faktor antiangiogenik. Faktor pro-angiogenik yang paling berperan dalam patogenesis PE adalah VEGF dan PlGF sedangkan faktor anti-angiogenik adalah sFlt-1 dan sEng. Pada pasien PE didapatkan peningkatan sFlt-1, dan sEng penurunan konsentrasi VEGF dan PIGF plasma dibandingkan pasien normotensi. ${ }^{8,11,12,23,35,43}$

Walaupun patogenesis secara pasti belum diketahui namun patogenesis PE secara ringkas diperlihatkan seperti pada Gambar 2.

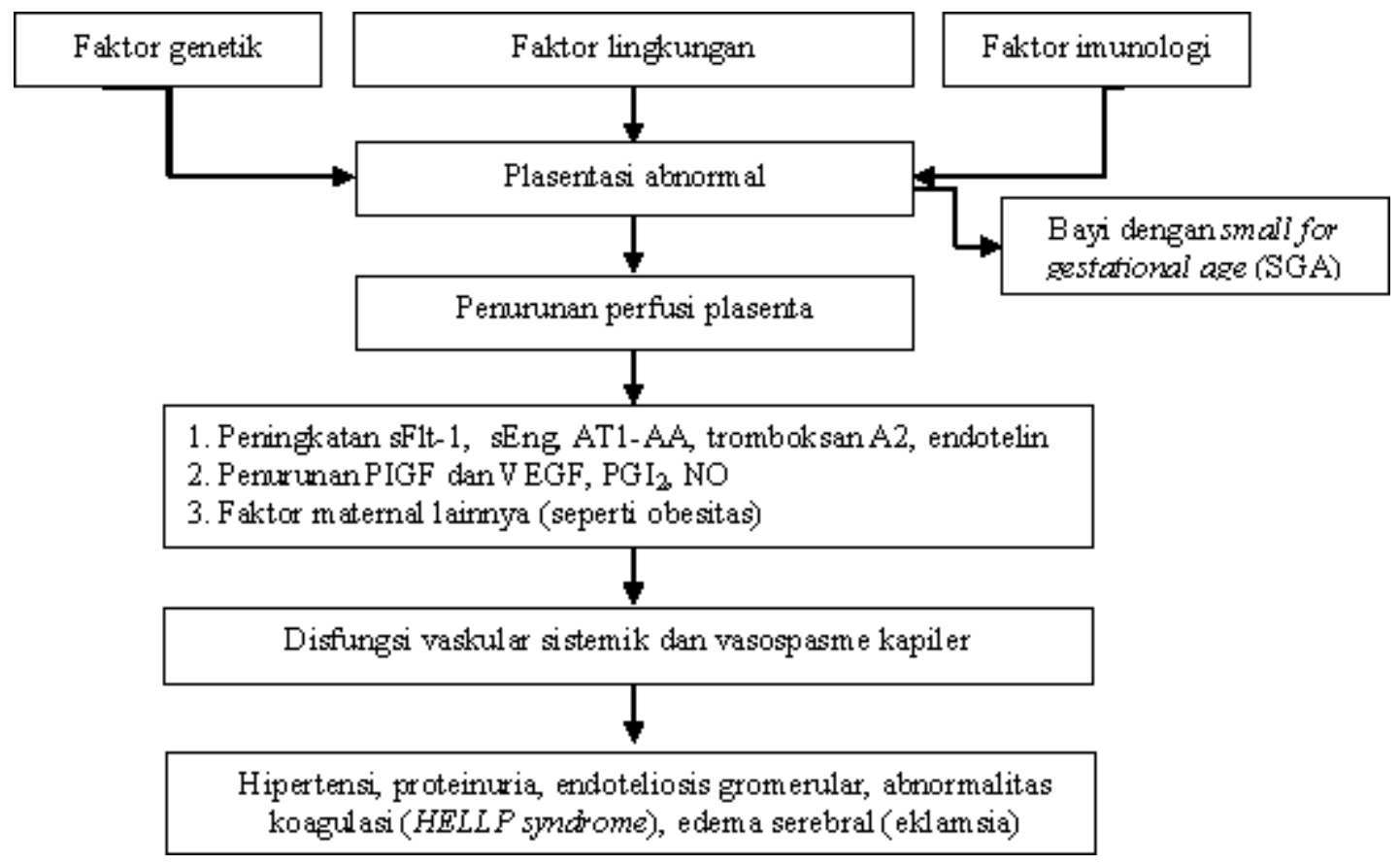

Gambar 2 Patogenesis Preeklamsia (Diadaptasi dari Lam et al, 2005). ${ }^{10}$ 
Pada Gambar 2 dapat kita lihat bahwa yang menjadi penyebab timbulnya vasospasme kapiler dan disfungsi vaskular secara sistemik adalah ketidakseimbangan faktor anti angiogenik dan proangiogenik disamping itu juga terlibat autoantibody against the angiotensin receptor-1 (AT1-AA) dan faktor maternal lainnya seperti obesitas. $^{10}$

Pada PE mRNA endoglin mengalami upregulasi dan melepaskan domain ekstraselular melalui proses proteolisis ke sirkulasi maternal membentuk sEng. Berbeda dengan endoglin, sEng merupakan protein antiangiogenik yang menghambat signal TGFâ-1 dalam pembuluh darah. Pada suatu studi menggunakan tikus yang diinjeksi dengan adenovirus yang kuat mengekpresikan sEng mengakibatkan peningkatan permeabilitas vaskular dan menginduksi hipertensi sedang tanpa proteinuria. Namun pada percobaan menggunakan adenovirus yang kuat mengekspresikan sEng dan sFlt-1 akibat yang ditimbulkan lebih dahsyat yaitu kerusakan vaskular berat, proteinuria, hipertensi berat, sindrom yang mirip dengan sindrome HELLP (hemolysis, elevated liver enzymes, low platelet) dan pertumbuhan janin terhambat. Berdasarkan hal tersebut maka dikatakan bahwa sEng dan sFlt-1 bekerja melalui mekanisme berbeda namun bersama-sama mengakibatkan disfungsi endotel dan PE berat. ${ }^{11}$

Faktor sFlt-1 dan sEng menyebabkan disfungsi endotelial dengan cara menghambat (antagonis) sinyal VEGF, PlGF dan TGF-âl. Bukti kuat menunjukkan bahwa VEGF dan TGF-âl diperlukan untuk menjaga kesehatan endotel diberbagai jaringan tubuh seperti ginjal dan plasenta. Selama kehamilan, homeostasis pembuluh darah dipertahankan oleh kadar fisiologis dari VEGF dan TGF-â1. Pada PE sekresi sFlt-1 dan sEng dari plasenta meningkat. sFlt-1 bisa berikatan dengan VEGF dan PIGF. Proses ini digambarkan seperti Gambar 3. Hal ini akan menghambat penyampaian sinyal ke reseptornya seperti VEGF-R1 and VEGFR2 yang juga dikenal dengan Flt-1 dan kinase domain region (Flk/KDR). ${ }^{39} \mathrm{Hal}$ ini akan menyebabkan terjadinya disfungsi sel endotel termasuk penurunan prostasiklin dan produksi NO, dan pelepasan protein-protein prokogulan. ${ }^{8}$

Fungsi sFlt-1 adalah sebagai umpan selama perkembangan dan mencegah VEGF berikatan dengan reseptor KDR. Peran sFlt-1 sebagai scavenger diduga terlibat dalam patogenesis preeklampsia. Peningkatan produksi sFlt-1 oleh plasenta preeklamptik menyebabkan konsentrasi PIGF dan VEGF bebas yang bersirkulasi rendah, karena terikat oleh sFlt-1. Hal ini menyebabkan signaling angiogenesis plasenta terganggu. Percobaan pada tikus hamil yang diinjeksi adenoviral yang mengekpresikan sFlt-1 menyebabkan tikus mengalami hipertensi, proteinuria dan endotelisis glomerular. ${ }^{39}$

Pada Gambar 3 dapat dilihat bahwa pada PE terdapat peningkatan sEng dan sFlt-1 yang dihasilkan dari pemotongan alternatif endoglin dan Flt-1 normal. Dari penelitian memperlihatkan bahwa peningkatan produksi kedua komponen ini disebabkan oleh keadaan hipoksia pada jaringan. ${ }^{13}$ Namun bagaimana mekanisme yang pasti belum dapat diketahui. Ikatan yang terbentuk antara sEng dengan TGF-â1 dan antara sFlt-1 dengan VEGF akan menyebabkan kelainan pembuluh darah berupa kegagalan dalam relaksasi. Hal ini berkaitan dengan regulasi Id1, eNOS dan PAI-1. ${ }^{44}$

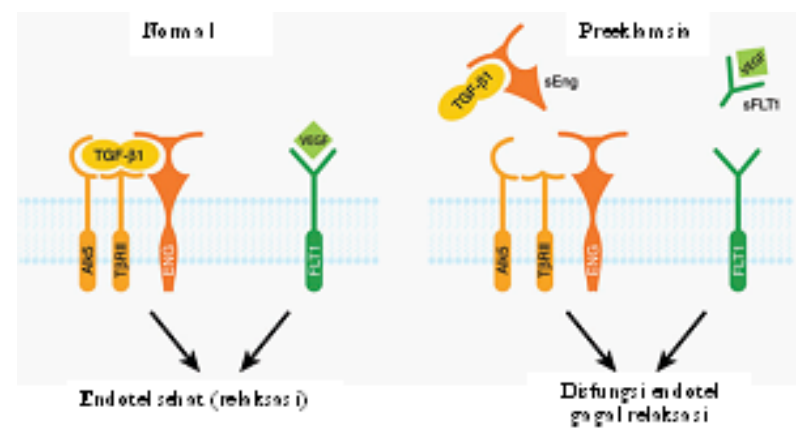

Gambar 3. Skematik Molekuler Perubahan Komponen Antiangiogenik (sEng dan sFlt-1) dari Endoglin dan Flt-1 (Diadaptasi dari Maynard et al, 2008). ${ }^{8}$ Perubahan ini menyebabkan hilangnya fungsi relaksasi pembuluh darah, sehingga menimbulkan manisfestasi klinis pada penderita PE.

Melihat dari peran yang dimainkan oleh sFlt-1 dan sEng, maka sudah sewajarnya kita berpikir untuk $\mathrm{m}^{2}$ enjadikan kedua komponen ini sebagai target site pengembangan terapi medikamentosa PE. Maynard menganalisis bahwa, pengembangan terapi PE pada masa mendatang adalah dengan menyeimbangkan kembali faktor angiogenik yang 
meliputi faktor proangiogenik seperti VEGF, PIGF dan TGFâ-1 serta faktor antiangiogenik yang meliputi sFlt-1 dan sEng. Ini dapat dilakukan dengan cara meningkatkan konsentrasi faktor proangiogenik relatif terhadap faktor antiangiogenik. ${ }^{8}$ Hal ini berdasarkan dari sebuah penelitian yang memperlihatkan bahwa dengan pemberian VEGF121 dapat menurunkan hipertensi dan proteinuria tampa pengaruh buruk terhadap fetus pada model mencit PE yang diinduksi sFlt-1. ${ }^{46}$ Ini cukup beralasan karena berdasarkan pembahasan terhadap model Gambar 3 menunjukkan bahwa pemberian sFlt-1 akan menurunkan transduksi sinyal VEGF pada sel endotel normal karena sFlt-1 akan berkompetisi dengan reseptor VEGF, sehingga jika ditambahkan VEGF maka makin banyak VEGF yang dapat berikatan dengan reseptornya.

Selain meningkatkan konsentrasi proangiogenik, hal yang juga mungkin dilakukan adalah mengurangi kerja faktor antiangiogenik atau bahkan menghambat produksinya. Metode untuk mengurangi pengaruh faktor anti-angiogenik adalah dengan menghasilkan suatu antagonis terhadap sFlt1 dan sEng. Sampai sekarang belum diketahui bahwa sFlt-1 dan sEng bermanfaat dalam tubuh, sehingga jika dihasilkan antagonisnya maka tidak akan memberikan pengaruh buruk terhadap tubuh maternal maupun fetus. Pengembangan ini cukup potensial karena berdasarkan analisis yang sudah dilakukan menunjukkan sFlt-1 dan sEng memainkan peran besar pada jalur utama patogenesis PE. Hal ini merupakan hal yang paling potensial sebelum penelitian untuk menentukan faktor perangsang pelepasan sFlt-1 dan sEng benar-benar berhasil walaupun penelitian memperlihatkan bahwa hipoksia merangsang pelepasan sFlt-1 dan sEng ${ }^{13}$ Oleh karena itu perlu dilakukan pencarian antagonis yang efektif terhadap sFlt-1 dan sEng pada masa mendatang, baik yang berasal dari komponen zat aktif tumbuhan atau hewan maupun komponen yang disintesis. Kita harus yakin bahwa akan ditemukan terapi medikamentosa yang benar-benar efektif terhadap PE pada masa mendatang sehingga dapat mengurangi mortalitas dan morbiditas maternal dan perinatal pada umat manusia.

\section{KESIMPULAN}

Peningkatan sFlt-1 dan sEng pada kehamilan akan menyebabkan hambatan transduksi sinyal faktor-faktor proangiogenik pada pembuluh darah sehingga menimbulkan berbagai manifestasi klinis pada pasien PE yaitu dengan cara berikatan dengan faktor proangiogenik yang meliputi VEGF, PIGF dan TGFâ-1. Antagonis Flt-1 dan sEng cukup potensial dijadikan sebagai terapi medikamentosa PE karena memegang jalur utama dalam patogenesis PE.

\section{SARAN}

Perlu dilakukan penelitian untuk menentukan jenis antagonis sFlt-1 dan sEng yang paling efektif dan meninjau ulang peran molekuler sFlt-1 dan sEng pada tubuh manusia. Selain itu penelitian yang mengarah kepada penentukan faktor penyebab perangsangan produksi sFlt-1 dan sEng perlu dilakukan lebih mendalam.

\section{DAFTAR PUSTAKA}

1. Emery PS. Hypertensive Disorders of Pregnancy: Overdiagnosis is Appropriate. Clev Clinic J Med 2005; 72(4): 345-52.

2. Wagner LK. Diagnosis and Management of Preeclampsia. American Family Physician 2004; 70(2): 2317-24.

3. WHO. World Health Report: Make Every Mother and Child Count. Geneva: World Health Org. 2005.

4. Duley L, Meher S dan Abalos E. Management of Preeclampsia. BMJ 2006; 332: 463-468

5. Huppertz B. Placental Origin of Preeclampsia: Challenging the Current Hypothesis. Hypertension 2008; 51:970-5.

6. Friedman SA, Lubarsky SL dan Lim K-H. Mild gestational hypertension and preeclampsia. In: Sibai BM, ed. Hypertensive Disorders in Women. Philadelphia: WB Saunders; 2001:9-23.

7. Lim KH, Watkins MM. Preeclampsia, eclampsia, and hypertension. In: Gronowski AM, ed. Current Clinical Pathology: Handbook of Clinical Laboratory Testing During Pregnancy. Totowa, NJ: Humana Press; 2004:391-400.

8. Maynard S, FH Epstein, dan SA Karumanchi. Preeclampsia and Angiogenic Imbalance. Annu. 
Rev. Med. 2008. 59:61-78

9. Lim J.H., S.Y. Kim, S.Y Park, et al. Effective Prediction of Preeclampsia by a Combined Ratio of Angiogenesis-Related Factors. Obstet Gynecol 2008;111:1403-9

10.Lam C, Lim KH dan Karumanchi SA. Circulating angiogenic factors in the pathogenesis and prediction of preeclampsia. Hypertension 2005;46:1077-85.

11.Levine RJ, Lam C, Qian C, et al. Soluble endoglin and other circulating antiangiogenic factors in preeclampsia. $N$ Engl $\mathrm{J}$ Med 2006;355:992-1005.

12. Venkatesha S, Toporsian M, Lam C, et al. Soluble endoglin contributes to the pathogenesis of preeclampsia. Nat Med 2006;12:642-9.

13.Ahmad S dan Ahmed A. Elevated placental soluble vascular endothelial growth factor receptor-1 inhibits angiogenesis in preeclampsia. Circ Res 2004;95:884-91.

14.Clausen T, Djurovic S, Reseland JE, et al. Altered plasma concentrations of leptin, transforming growth factor-beta (1) and plasminogen activator inhibitor type 2 at 18 weeks of gestation in women destined to develop pre-eclampsia. Circulating markers of disturbed placentation? Placenta 2002;23:380-5.

15.Unal ER, Robinson CJ, Johnson DD, et al. Second trimester angiogenic factors as biomarkers for future-onset preeclampsia. Am J Obstet Gynecol 2007;197:2111-4.

16. Moore STA, Crawford SL, Solitro MJ, et al. Angiogenic factors for the prediction of preeclampsia in high-risk women. Am J Obstet Gynecol 2007;197:2441-8.

17.Su YN, Lee CN, Cheng WF, et al. Decreased Maternal Serum Placental Growth Factor on Early Second Trimester and Preeclampsia. Obstet Gynecol 2001; 97: 898-904.

18. Tidwell, SC, Ho HN, Chiu WH, et al. Low maternal serum levels of placenta growth factor as an antecedent of clinical preeclampsia. Am J Obstet Gynecol. 2001;184:1267-72.

19. Ong CY, Liao AW, Cacho AM, et al.Firsttrimester maternal serum levels of placenta growth factor as predictor of preeclampsia and fetal growth restriction. Obstet Gynecol. 2001;98: 608-11.

20.Polliotti BM, Fry AG, Saller DN, et al. Secondtrimester maternal serum placental growth factor and vascular endothelial growth factor for predicting severe, early-onset preeclampsia. Obstet Gynecol. 2003;101:1266 -74.

21.Thadhani R, Mutter WP, Wolf M, et al. First trimester placental growth factor and soluble fms-like tyrosine kinase 1 and risk for preeclampsia. J Clin Endocrinol Metab. 2004;89:770 -5.

22.Hertig A, Berkane N, Lefevre G, et al. Maternal serum sFlt-1 concentration is an early and reliable predictive marker of preeclampsia. Clin Chem. 2004;50:1702-3.

23. Chaiworapongsa T, Romero R, Kim YM, et al. Plasma soluble vascular endothelial growth factor receptor- 1 concentration is elevated prior to the clinical diagnosis of pre-eclampsia. $J$ Matern Fetal Neonatal Med. 2005;17:3-18

24.Levine RJ, Thadhani R, Qian C, et al. Urinary placental growth factor and risk of preeclampsia. JAMA. 2005;293:77-85.

25. Vivo AD. Endoglin, PlGF and sFlt-1 as markers for predicting pre-eclampsia. Acta Obstetricia et Gynecologica. 2008; 87: 837-42

26. Mutter WP dan S. A. Karumanchi. Molecular mechanism of preeclamsia. Microvasc Res. 2008; 75(1): 1-8.

27.Wang A. S. Rana, dan SA Karumanchi. Preeklamsia: The role of Angiogenic Factor in its pathogenesis. 2009. Physiology 24 (3) 14758.

28.Walker JJ. Pre-eclampsia. Lancet. 2000;356:1260 -5.

29.Dekker GA. Risk factors for preeclampsia. Clin Obstet Gynecol. 1999; 42:422- 35.

30.Sibai B, Dekker G dan Kupferminc M. Preeclampsia. Lancet 2005;365:785-99.

31. Society of Obstetricians and Gynaecologists of Canada (SOGC). 2008.

32.Cetin I, Cozzi V, Pasqualini F, et al. Elevated maternal levels of the long pentraxin 3 (PTX3) 
in preeclampsia and intrauterine growth restriction. Am J Obstet Gynecol 2006;194:1347-53.

33. Qiu C, Saito S, Sakai M, et al. Plasma Granulysin Concentrations and Preeclampsia Risk. Clin Biochem 2006; 39(10): 1016-21

34.Carty DM, Delles C, dan Dominiczak AF, Novel Biomarkers for Predicting Preeclampsia. Trends Cardiovasc Med 2008; 18(5-24): 186-94.

35.Levine RJ, Maynard SE, Qian C, et al. Circulating angiogenic factors and the risk of preeclampsia. N Engl J Med 2004;350:672- 83.

36.Romero R, Chaiworapongsa T, Kim YM, et al. Plasma soluble vascular endothelial growth factor receptor-1 concentration is elevated prior to the clinical diagnosis of pre eclampsia. $J$ Matern Fetal Neonatal Med 2005;17:3-18.

37.Chappell LC, Seed PT, Briley A, et al. A longitudinal study of biochemical variables in women at risk of preeclampsia. Am J Obstet Gynecol 2002;187:127-36.

38. Grill S. Potential markers of preeclampsia - a review. Reprod Biol and Endocrinol 2009; 7:70

39.Krysiak O, Bretschneider A, Zhong E, et al. Soluble Vascular Endothelial Growth Fator receptor-1 (sFlt-1) Mediates Downregulation of FLT-1 and Prevents Activated Netrophils From Women with Preeclampsia from Additional Migration by VEGF. Circ Res 2005; 97: 125361.

40.He H, Venema VJ, Gu X, et al. Vascular endothelial growth factor signals endothelial cell production of nitric oxide and prostacyclin through Flk-1/KDR activation of c-Src. J Biol Chem. 1999;274:25130 -35.

41.Gerretsen G, Huisjes HJ dan Elema JD. Morphological changes of the spiral arteries in the placental bed in relation to pre-eclampsia and fetal growth retardation. Br J Obstet Gynaecol 1981;88:876-81.

42.Luft FC. Soluble Endoglin (sEng) Joins The Soluble fms-like Tyrosine Kinase (sFlt) Receptor as a Preeclampsia Molecule. Nephrol Dial Transplant 2006; 21: 3052-3054.

43. Maynard SE, Min JY, Merchan J, et al. Excess placental soluble fms-like tyrosine kinase 1 (sFlt1) may contribute to endothelial dysfunction, hypertension, and proteinuria in preeclampsia. J Clin Invest 2003;111:649-58.

44.Bernabeu C, Barbara AC, dan Calvin P.H. Vary. Novel Biochemical Pathways of Endoglin in Vascular Cell Physiology. J Cell Biochem 2007;102(6):1373-88.

45. Toporsian M, Gros R, Kabir MG, et al. A role for endoglin in coupling eNOS activity and regulating vascular tone revealed in hereditary hemorrhagic telangiectasia. Circ Res 2005; 96:684-92.

46.Li Z, Zhang Y, Ying Ma J, et al. Recombinant vascular endothial growth factor 121 attenuates hypertension and improves kidney damage in a rat model of preeclampsia. Hypertension. 2007; 50:686-92. 